\title{
ЛЕЙОМІОМА МАТКИ І БЕЗПЛІДДЯ (ОГЛЯД ЛІТЕРАТУРИ)
}

\author{
ДВНЗ «Тернопільський державний медичний університет \\ імені І.Я. Горбачевського МОЗ України», м. Тернопіль, Україна
}

\begin{abstract}
Мета: провести аналіз сучасної вітчизняної та зарубіжної літератури стосовно причин виникнення, етіопатогенезу лейоміоми матки, сучасних методів лікування та впливу даної патології на фрертильність жінки.

Матеріали і методи. У дослідженні використано бібліосемантичний та аналітичний методи.

Результати. Під час виконання дослідження було проведено огляд та проаналізовано 34 джерела сучасної вітчизняної та зарубіжної літератури щодо питання лейоміоми матки та її впливу на стан репродуктивного здоров'я жінки.

Висновки. На сьогодні питання вибору оптимальної тактики лікування лейоміоми залишається дуже дискусійним. Комбінована терапія з використанням сучасних технік (органозберігаючих операцій, емболізація маткових артерій, сорокусований ультразвук під контролем МРТ) та досягнень фрармакотерапії (уліпристал, міфепристон, аГнРГ) $€$ пріоритетним напрямком у сучасній гінекології. За допомогою даних методів лікування вдається зберегти та реалізувати репродуктивний потенціал жінок репродуктивного віку з лейоміомою матки.
\end{abstract}

КЛЮчОВІ СЛОВА: лейоміома матки; безпліддя; допоміжні репродуктивні технології; репродуктивне здоров'я; фертильність; консервативна міомектомія; емболізація маткових артерій.

На сьогодні репродуктивне здоров'я жінки є актуальною проблемою акушерства та гінекології, тому важливим є своєчасна діагностика та попередження захворювань, що впливають на фертильність.

Мета роботи: провести аналіз сучасної вітчизняної та зарубіжної літератури стосовно причин виникнення, етіопатогенезу лейоміоми матки, сучасних методів лікування та впливу даної патології на фертильність жінки.

Матеріали і методи. У дослідженні використано бібліосемантичний та аналітичний методи.

Результати дослідження та їх обговорення. Під час виконання дослідження було проведено огляд та проаналізовано 34 джерела сучасної вітчизняної та зарубіжної літератури щодо питання лейоміоми матки та її впливу на стан репродуктивного здоров'я жінки.

Лейоміома матки (ЛМ) - гормонозалежна доброякісна пухлина міометрія. Пухлина розвивається із однієї аномальної клітини, яка внаслідок перенесених у ній мутацій, набуває здатності нерегульованого росту. Тригер цієї мутації наразі невідомий [7]. Частота виникнення цієї патології у структурі гінекологічних захворювань, за даними різних авторів, коливається в межах від 20 до 50 \% у жінок репродуктивного віку [3, 4, 6]. Частота фріброміом збільшується з віком та під час вагітності. Найчастіше міому матки виявляють у жінок віком старше 35 років. Пік захворювання припадає на 35-45 років. Останнім часом спостерігається тенденція до виявлення цієї патології у молодих жінок віком до 20-25 років, що пов'язано зі спадковим характером захворювання. ЛМ є найпоширенішою доброякісною пухлиною репродуктивної системи жінки. Кількість операцій $з$ приводу міоми матки складає близько 80 \% від загальної кількості операційних втручань в гінекології [6]. Лейоміома посідає друге місце серед гінекологічних захворювань після запальних захворювань матки та придатків.

До фракторів ризику, які призводять до виникнення лейоміоми є: раннє чи пізнє менархе, рясні менструації, висока частота медичних абортів, наявність екстрагенітальної патології (особливо серцево-судинної), ендокринопатії, гіперестрогенії, гінекологічних захворювань (ендометріоз, аденоміоз, запальні захворювання статевих органів), тривала антибіотикотерапія, використання різних гормональних препаратів, внутрішньоматкова контрацепція, зниження імунітету $[11,12]$. Простежується спадкова схильність до розвитку цього захворювання [5, 12]. Існує кілька клінічних та епідеміологічних спостережень, які вказують на те, що генетичні чи хромосомні зміни відіграють значну роль у розвитку лейоміоми матки. Наприклад, жінки 3 обтяженим спадковим анамнезом мають більший ризик розвитку лейоміом порівняно 3 жінками 3 необтяженим спадковим анамнезом. Крім того, було повідомлено, що монозиготні близнюки мають більше шансів розвитку лм порівняно з різнояйцевими близнюками.

Лейоміома матки без сумніву $є$ гормонозалежною пухлиною. Провідну роль в етіології відіграють гормональні порушення, доведений вплив статевих гормонів - естрогенів, прогестерону та їх

() С.В. Хміль, І.В. Корда, Ю.Б. Дроздовська, М.С. Хміль, Н.Я. Чудійович, 2017 
рецепторів [17]. Тривалий час ключову роль у рості міоматозних вузлів відводили естрогенам. Проте результати останніх досліджень вказують на важливу роль прогестерону в патогенезі міом [5, $10,12]$. Доказами є дані про пришвидшений ріст ЛМ та збільшення експресії Кі-67 (антиген клітинної проліферації) у лютеїновій фразі менструального циклу. Деякі автори розглядають розвиток міом із позицій апоптозу. В багатьох роботах доведено вплив статевих гормонів не лише на проліферативні процеси, а також і на регуляцію апоптозу в міометрії [10, 33]. У реалізації впливу статевих гормонів беруть участь місцеві ауто- та паракринові фрактори (цитокіни, фрактори росту та ін.), продукція яких контролюється впливом естрогенів та прогестерону. Встановлено, що протеїн Вс1-2, який гальмує апоптоз, значно менше експресується при ЛМ порівняно з нормальним міометрієм. До того ж естрадіол, який пригнічує експресію цього протеїну, знижує апоптоз. Мітогенна дія естрогенів опосередкована місцевими регулюючими фракторами росту. Результатом їх надлишкової продукції $€$ гіпертрофрія клітин, пришвидшення клітинної проліферації, збільшення об'єму міжклітинного матриксу та поєднання цих явищ. Найвагомішим фрактором росту для міоматозних вузлів вважають трансформуючий фактор росту- $\beta$ (ТФР- $\beta$ ), стимулюючий вплив на продукцію якого здійснює прогестерон. Естрогени впливають на міжклітинний матрикс, здійснюючи прямий вплив на колаген I і III типу та протеїн коннексин-43 міжклітинних зв'язків. Основними модуляторами клітинного росту, що володіють вираженою мітогенною активністю на міометрій та тканину пухлини є ІПФР-1, епідермальний фрактор росту, ТФР- $\beta$ і група ангіогенних фракторів росту. На даний час дослідники розглядають роль ангіогенезу в патогенезі лМ. Основними індукторами ангіогенезу є судинний ендотеліальний фрактор росту (VEGF), ангіогенін та основний фрактор росту фрібробластів (FGF) [25]. Процеси ангіогенезу в міомах нерозривно пов'язані 3 морфогенезом пухлин та значною мірою визначають характер росту та клініко-морфологічні варіанти ЛМ (проста, проліферуюча) [10]. Дані про вплив статевих гормонів на механізм виникнення міом дають можливість визначення тактики медикаментозного лікування даного захворювання.

Жінки, які не народжували, зі збільшенням віку мають більший ризик розвитку лМ. Міома матки може бути поодинокою або множинною та розвивається в тілі або, рідше, шийці матки, круглих зв'язках. Оскільки міоми виникають у міометрії, на початку свого розвитку всі вони є інтрамуральними і залежно від напрямку росту (центрипетального або ексцентричного) стають субмукозними або субсерозними [10]. Більшість міом безсимптомні, їх виявляють під час профрілактичного гінекологічного дослідження або ультрасонографії. Приблизно у 50 \% пацієнток клінічні симптоми залежать від розміру, локалізації та кількості міом. Найпоширеніші симптоми для цієї патології: тяжкі та тривалі менструальні кровотечі, анемія (вторинна - від надмірної менструальної крововтрати), біль та тиск у ділянці малого таза, дисменорея, нетримання сечі, закрепи, біль у спині, сексуальна дисфункція, безпліддя, мимовільні викидні та стиснення сусідніх органів при вузлах великих розмірів [11, 12]. Міома може швидко рости. Біль, як правило, локалізується в нижніх відділах живота і попереку. Часто виражена тривалість болю пов'язана зі швидким ростом пухлини. Гострий біль виникає головним чином при порушеннях кровопостачання в пухлині, його прогресування може призвести до розвитку клінічної картини гострого живота. Переймоподібний біль під час менструації може свідчити про підслизове розташування вузла. Частими ускладненнями фріброміоми є безпліддя, мимовільні викидні й інші ускладнення вагітності [12].

Міома матки часто впливає на репродуктивну функцію жінок. Певну роль у розвитку безпліддя при ЛМ відіграють механічні фрактори. При субмукозних та перешийкових розташуваннях міоматозного вузла виникає порушення транспорту та міграції сперматозоїдів; інтралігаментарні вузли великих розмірів (більше 5-6 см), субмукозні та вузли з локалізацією в ділянці трубних кутів матки призводять до порушення транспорту яйцеклітини; підвищена чи порушена скоротлива діяльність міометрія у хворих 3 інтрамуральними вузлами чи при множинній лейоміомі спричиняє порушення імплантації ембріона [12]. Таким чином, спираючись на дані сучасних дослідників, лМ у 20-30 \% призводить до безпліддя та в 15-30 \% випадків $є$ причиною невиношування вагітності [13, 16, 31].

Існує безліч дискусій щодо впливу лейоміоми матки на результати допоміжних репродуктивних технологій (ДРТ). Міоматозні вузли знижують частоту позитивних результатів екстракорпорального запліднення (ЕКЗ) і підвищують частоту самовільних викиднів. У ряді досліджень було показано, що субмукозні вузли погіршують імплантацію та настання вагітності при ЕКЗ [16, 24]. Видалення субмукозних вузлів за допомогою гістерорезектоскопії значно підвищує результат ЕКЗ. У метааналізі S. K. Sunkara (2010), в якому оцінювався перебіг та результати більш ніж 6000 циклів ЕКЗ, показано зниження частоти настання клінічної вагітності та пологів у жінок 3 інтрамуральною лейоміомою матки [32]. У роботі Suleyman Guven, Cavit Kart та співавторів було підтверджено, що інтрамуральна лейоміома (d<7cm), без деформації порожнини матки, також негативно впливає на результати допоміжних репродуктивних технологій порівняно з контрольною групою жінок без цієї патології, вибрано оптимальний метод лікування 
перед проведенням ЕКЗ - консервативна міомектомія [18].

Фіброміома матки асоціюється зі збільшенням частоти спонтанних абортів (41\%), кількість яких зменшується після консервативної міомектомії (19 \%). Причинами можуть бути порушення маткового кровотоку, зменшення кровопостачання ендометрія, дисторсія порожнини матки, швидкий ріст або дегенерація міоми матки під час вагітності, порушення механізмів збільшення порожнини матки внаслідок міоми, гірші умови для імплантації заплідненої яйцеклітини [19, 20, 24].

Лікування міоми матки у репродуктивному віці потребує вибору оптимальної тактики ведення пацієнтів, необхідно враховувати розміри, кількість та особливості розташування міоматозних вузлів. Терапію потрібно розпочинати якомога швидше. Тривале спостереження за хворими (3-5 років та більше) призводить до прогресування захворювання: росту міоматозних вузлів, посилення маткових кровотеч, що призводять до виникнення залізодефіцитної анемії, гіперпластичних процесів ендометрія, системних порушень в організмі [18]. Основними підходами до лікування лейоміоми матки є: консервативне медикаментозне лікування, операційне лікування та емболізація маткових артерій [6].

Основне завдання гормональної терапії це створення відносної та абсолютної гіпоестрогенії. Ефективність прогестагенів та оральних контрацептивів проявляється усуненням клінічних симптомів пухлини, зменшенням менструальних крововтрат зі значним підвищенням рівня гематокриту. На розміри матки препарати не впливають [29]. Застосування препаратів антипрогестеронової дії (міфепристон, уліпристал ацетат) призводить до зменшення об'єму матки на 26,5\%. На сьогодні міфепристон офріційно рекомендований ВОО3 у дозі 50 мг на основі міжнародних досліджень - Кокранівський огляд 2012 р. [21, 27, 34]. У клінічних дослідженнях доведено, що використання уліпристалу (Есмія «Gedeon Richter») в дозі 5 та 10 мг одноразово протягом 12 тижнів у хворих із міомою матки сприяло зупинці маткових кровотеч, корекції анемії та зменшенню об'єму міоми [1, 26, 27].

Тимчасова медикаментозна менопауза досягається застосуванням агоністів ГнРГ (аГнРГ). Під час використання аГнРГ відзначається зменшення розмірів лейоміоми на 30-50 \%, що супроводжується вегетосудинними, психопатологічними та метаболічними порушеннями (застосовують препарат не довше ніж 3-5 місяців). Багато зарубіжних та вітчизняних дослідників рекомендують використання аГнРГ перед операційним лікуванням. Використання цієї групи препаратів може дозволити виконати міомектомію у жінок із вузлами великих розмірів, які хочуть зберегти та реалізувати репродуктивну функцію в подальшому, зменшує об'єм інтраопераційної крововтрати та полегшує енуклеацію міоматозного вузла [2, 29].

Операційне лікування міоми матки включає гістеректомії та органозберігаючі операції - консервативну міомектомію, яка може бути виконана залежно від показань, вагінальним, трансцервікальним, лапароскопічним або абдомінальним доступом. Показання до консервативної міомектомії є бажання жінки зберегти матку, менструальну функцію та відновлення фертильності, невиношування або безпліддя при лейоміомі матки, симптомна лейоміома матки.

Прийнято вважати, що анатомічне місце розташування фріброміоми матки (субмукозне, інтрамуральне, субсерозне), як правило, є важливим фрактором у визначенні плану лікування безпліддя [9]. При субмукозній фріброміомі матки вона може бути ефективно видалена за допомогою гістерорезектоскопії [8, 10]. При інтрамуральній або субсерозній фріброміомі використовують лапароскопічну або лапаротомну консервативну міомектомію [8]. Але операційне лікування може інколи призводити до виникнення безпліддя та погіршити репродуктивну функцію через формування злукового процесу органів малого таза, рубців на матці. Думки авторів відносно впливу операційного лікування (консервативної міомектомії) на відновлення фертильності також різні: L. I. Zepiridis et al. (2016) показали покращення результатів лікування безпліддя при будь-яких видах консервативної міомектомії [23], тоді як т. Samejima et al. (2015) виявили, що проведення консервативної міомектомії дозволяє вирішити проблему безпліддя тільки в тих жінок, у яких міома була єдиною причиною безпліддя, зокрема при субмукозному розташуванні [30]; у той час, як видалення інтрамуральних вузлів може не впливати на ефективність лікування безпліддя. Підвищує ефективність консервативної міомектомії застосування комбінованої терапії (аГнРГ, есмія).

На сьогодні перспективним напрямком органозберігаючого лікування лейоміоми матки $є$ емболізація маткових артерій (ЕMA), яка $є$ альтернативою хірургічним втручанням [22]. У багатьох дослідженнях було показано високу ефективність ЕMA: зменшення в розмірах міоматозних вузлів, зменшення частоти менорагій, регрес больового синдрому. Доведено перевагу для жінок, які перенесли дану процедуру: значно коротший час перебування в стаціонарі та відновлення працездатності, порівняно $з$ пацієнтками, які перенесли гістеректомію чи консервативну міомектомію $[14,25]$. Також у ряді досліджень були висвітлені акушерські ускладнення після ЕMA: це мимовільні викидні, передчасні пологи, передлежання плаценти, післяродові кровотечі $[14,15]$. Американський коледж акушерства та гінекології (ACOG) на основі проведених досліджень прийшов до висновку, що емболізація 
маткових артерій $є$ безпечним та ефрективним варіантом лікування у жінок, які хочуть зберегти матку. Варто зазначити, що ризик радіаційного опромінення та ретроградної емболізації може призвести до передчасної недостатності яєчників, атрофрії ендометрія $[18,19]$. Незважаючи на великий досвід використання EMA в лікуванні міом, на даний час не існує єдиної думки відносно можливості рекомендувати цей вид лікування пацієнткам із нереалізованою репродуктивною функцією.

Протягом останніх років відносно новим органозберігаючим методом у лікуванні ЛМ є сорокусований ультразвук під контролем МРТ (ФУЗ-МРТ), який забезпечує точкову коагуляцію тканини міоми [18]. У результаті проведеного лікування відбувається деструкція міоматозного вузла. У своїй роботі F. M. Fenessy, C. М. Tempany відзначили зменшення розмірів міоми через 3 місяці на $37 \%$, через 6 місяців на $48 \%$ [28].

\section{Висновки}

Лейоміома матки є однією з найактуальніших проблем у сучасній гінекології. Все частіше ця патологія виникає у молодих жінок із нереалізованим репродуктивним потенціалом, як наслідок призводять до ряду ускладнень: зниження репродуктивної фрункції та безпліддя. На сьогодні питання вибору оптимальної тактики лікування лейоміоми залишається дуже дискусійним. Комбінована терапія з використанням сучасних технік (органозберігаючих операцій, EMA, МРТ-ФУЗ) та досягнень фрармакотерапії (уліпристал, міфепристон, аГнРГ) є пріоритетним напрямком у сучасній гінекології. За допомогою цих методів лікування вдається зберегти та реалізувати репродуктивний потенціал жінок репродуктивного віку з лМ.

Перспективою подальших розробок буде вивчення впливу лейоміоми матки на результати допоміжних репродуктивних технологій у жінок із безпліддям та нереалізованим репродуктивним потенціалом.

\section{Список літератури}

1. Адамян Л. В. Антипролиферативное и проапоптотическое действие селективного модулятора рецепторов прогестерона улипристала на лейомиому матки in vitro / Л. В. Адамян, О. В. Зайратьянц, А. Л. Тихомиров // Проблемы репродукции. - 2014. - № 3. - С. 41-44.

2. Адамян Л. В. Новые подходы к медикаментозному лечению симптомной миомы матки (обзор литературы) /

Л. В. Адамян, А. В. Козаченко, 3. В. Ревазова // Проблемы репродукции. - 2013. - Т. 3. - С. $22-24$.

3. Антагонисты рецепторов прогестерона в структуре комплексного органосохраняющего лечения миомы матки / А. Л. Тихомиров, А. А. Леденкова, А. Е. Батаева, В. Г. Абышова // Акушерство и гинекология. - 2012. - № 5. C. $115-119$.

4. Бойко В. І. Диференційований підхід до хірургічного лікування міоми матки великих розмірів / В. І. Бойко, В. А. Терехов // Здоровье женщины. - 2016. - № 7 (113). - С. 57-61.

5. Вдовиченко Ю. П. Лейоміома матки: етіопатогенез, профрілактика, діагностика та лікування / Ю. П. Вдовиченко, О. В. Голяновський, В. І. Лепушин // Здоровые женщины. - 2012. - № 3 (69). - С. 52-61.

6. Жилка Н. Я. Інноваційні підходи до лікування лейоміоми матки / Н. Я. Жилка // Здоровье женщины. - 2016. № 7 (113). - С. 104-106.

7. Запорожан В. М. Акушерство та гінекологія : національний підручник/ В. М. Запорожан, Т. Ф. Татарчук, І. 3. Гладчук ; за ред. В. М. Запорожана. - К. : ВСВ «Медицина», 2014. - Т. 4. - С. 290-321.

8. Панфрамиров Ю. Н. Органосберегающий подход в лечении миомы матки / Ю. Н. Панорамиров, В. А. Заболотнов, О. В. Карапетян // Здоровые женщины. - 2013. - № 1 (77). - С. 162-164.

9. Принципы лечения лейомиомы матки / Н. В. Косей, Л. А. Васильченко, Э. И. Сухоребрал, И. И. Шокало // Репродуктивная эндокринология. - 2012. - № 1 (3). - С. 14-20.

10. Сидорова И. С. Миома матки (современные аспекты этиологии, патогенеза, классификации и профилактики) / Миома матки ; под ред. И. С. Сидоровой. - М. : МИА, 2013. - С. 5-66.

11. Сторожук М. С. Клінічна характеристика жінок репродуктивного віку, хворих на міому матки / М. С. Сторожук, О. О. Проценко, О. Б. Мартинишин // Здоровые женщины. - 2012. - № 7 (73). - С. 16-157.

12. Сучасні погляди на етіологію, патогенез та лікування лейоміоми матки у жінок репродуктивного віку (огляд літератури) / А. Г. Корнацька, І. І. Ракша, І. С. Колесниченко, Г. В. Чубей // Здоровые женщины. - 2015. - № 1 (97). C. $10-13$.

13. Сучасні погляди репродуктолога на етіопатогенез і лікування лейоміоми матки / Н. В. Авраменко, Д. Є. Барковський, О. В. Кабаченко, Д. В. Лецин // Запорізький медичний журнал. - 2017. - Т. 19, № 3 (102). С. 381-386.

14. Чайка К. В. Комплексное эндохирургическое лечение женщин репродуктивного возраста с субмукозной миомой матки / К. В. Чайка, О. Л. Писарева // Медико-соціальні проблеми сім'ї. - 2013. - Т. 18, № 3. - С. 63-67.

15. Шарафутдинов Б. М. Оптимизация рентгенэндоваскулярной эмболизации маточных артерий при лечении больных с миомами матки и маточными кровотечениями / Б. М. Шарафрудинов, Р. Ф. Акберов, А. 3. Шарафеев // Практическая медицина. - 2015. - № 1 (86). - С. 94-97.

16. Alterations in uterine hemodynamics caused by uterine fibroids and their impact on in vitro fertilization outcomes / JeiWon Moon, Chung-Hoon Kim, Jun-Bum Kim [et al.] // Clin. Exp. Reprod. Med. - 2015. - Vol. 42 (4). - P. 163-168.

17. Cell-type specific actions of progesterone receptor modulators in the regulation of uterine leiomyoma growth / S. Yoshida, N. Ohara, Q. Xu [et al.] // Semin. Reprod. Med. - 2010. - Vol. 28. - P. 260-273. 
18. Clark N. A. Reproductive impact of MRI-guided focused ultrasound surgery for fibroids: a systematic review of the evidence / N. A. Clark, S. L. Mumford, J. H. Segars // Curr. Opin. Obstet. Gynecol. - 2014. - Vol. 26 (3). - P. $151-161$. 19. Deligdish L. Endometrial changes associated with myomata of uterus // L. Deligdish, M. Loewenthal // J. CHn Pathol. 2014. - No. 23. - P. 676-680.

20. Foissac R. Torsion of a huge pedunculated uterine leiomyoma / R. Foissac, N. Sautot Vial, L. Birtwisle // Am. J. Surg. 2015. - Vol. 201. - P. 43-45.

21. GSTM1 gene expression correlates to leiomyoma volume regression in response to mifepristone treatment / M. Engman, S. Varghese, Kr. Lagerstedt Robinson [et al.] / PLoS One. - 2013. - Vol. 8 (12).

22. Hysteroscopy after uterine fibroid embolization: evaluation of intrauterine findings in 127 patients / M. Mara, P. Horak, K. Kubinova [et al.] // J. Obstet. Gynaecol. Res. - 2012. - Vol. 38. - P. 823-831.

23. Infertility and uterine fibroids / L. I. Zepiridis, G. F. Grimbizis, B. C. Tarlatzis [et al.] // Best Pract. Res. Clin. Obstet. Gynaecol. - 2016. - Vol. 34. - P. 66-73.

24. Intramural leoimyoma without endometrial cavity distortion may negatively affect the ICSI - ET outcome / S. Guven, C. Kart, M. A. Unsal, E. Odaci // Reprod. Biol. Endocrinol. - 2013. - Vol. 11. - P. 102. doi: 10.1186/1477-7827-11-102

25. Mauro A. Effect of antiprogesterone RU486 on VEGF expression and blood vessel remodeling on ovarian follicles before ovulation / A. Mauro, A. Martelli, P. Berardinelli // PLoS One. - 2014. - Vol. 9 (4). - P. e95910

26. Pohl O. The clinical pharmacology and pharmacokinetics of ulipristal acetate for the treatment of uterine fibroids $/$ O. Pohl, R. H. Zobrist, J.-P. Gotteland // Reprod. Sci. - 2015. - Vol. 22 (4). - P. 476-483.

27. Pohl O. Ulipristal acetate - safety and pharmacokinetics following multiple doses of 10-50 mg per day / O. Pohl, I. Osterloh, J. P. Gotteland // J. Clin. Pharm. Ther. - 2013. - Vol. 38 (4). - P. 314-320.

28. Potential of minimally invasive procedures in the treatment of uterine fibroids: a focus on magnetic resonanceguidetfocused ultrasound therapy / K. Fischer, N. J. McDannold, C. M. Tempany // Int. J. Womens Health. - 2015. Vol. 7. - P. 901-912.

29. Sabry M. Innovative oral treatments of uterine leiomyoma / M. Sabry, A. Al-Hendy // Hindawi Publishing Corporation, Obstetrics and Gynecology International. - P. 1-10. Article ID 943635, doi:10.1155/2012/943635

30. Identifying patients who can improve fertility with myomectomy / T. Samejima, K. Koga, H. Naake [et al.] // Eur. J. Obstet. Gynecol. Reprod. Biol. - 2015. - Vol. 185. - P. 28-32.

31. Shchukina N. A. The clinical and morphological features of uterine myoma in young women / N. A. Shchukina, E. N. Sheina, I. V. Barinova // Rossiysky vestnik akushera ginekologa. - 2014. - No. 5. - P. 28-31.

32. Sunkara S. K. The effects of intramural fibroids without uterine cavity involvement on the outcome of IVF treatment: a systematic review and meta-analysis / S. K. Sunkara, M. Khairy, T. El-Toukhy [et al.] // Hum. Reprod. - 2010. Vol. 25 (2). - P. 418-429.

33. Suzuki K. Recombinant $\mathrm{H} 2$ relaxin inhibits apoptosis and induces cell proliferation in ultured leiomyoma cells without affecting those in cultured normal myometrial cells / K. Suzuki, K. Nakabayashi, A. Y. Yamada // Fertil Steril. - 2012. Vol. 97 (3). - P. 734-741.

34. Tristan M. Mifepristone for uterine fibroids / M. Tristan, L. J. Orozco, A. Steed // Cochrane Database Syst. Rev. - 2012. Issue 8. CD007687.

\section{References}

1. Adamyan, L.V., Zayratyants, O.V. \& Tikhomirov, A.L. (2014). Antiproliferativnoe i proaspoptoticheskoe deystviye selektivnogo modulyatora retseptorov progesteronu ulypristala na leyomiomu matky in vitro [Antiproliferative and proaspototic activity of the selective receptor modulator progesterone was applied to the uterine leiomyoma in vitro]. Problema reproduktsyi - The Problem of Reproduction, 3, 41-44 [in Russian].

2. Adamyan, L.V., Kozachenko, A.V. \& Revazova, Z.V. (2013). Novyye podkhody k medykamentoznomu lecheniyu simptomnoy miomy matki (obzor literatury) [New approaches to drug treatment of symptomatic uterine myoma (literature review)]. Problemy reproduktsyi - Reproduction Problems, (3), 22-24 [in Russian].

3. Tikhomirov, A.L., Ledenkova, A.A., Batayeva, A.E. \& Abishova, V.G. (2012). Antagonisty retseptorov progesterona v strukture kompleksnogo organosokhranyayushchego lecheniya miomy matki [Progesterone receptor antagonists in the structure of complex organ-preserving treatment of uterine myoma]. Akusherstvo i ginekologiya - Obstetrics and Gynecology, 5, 115-119 [in Russian].

4. Boyko, V.I. \& Terekhov V.A. (2016). Dyferentsiiovanyi pidkhid do khirurhichnoho likuvannia miomy matky velykykh rozmiriv [Differentiated approach to surgical treatment of large uterine fibroids] Zdorovie zhenshchiny - Health of Women, 7 (113), 57-61 [in Ukrainian].

5. Vdovychenko, Yu.P., Holyanovskyy, O.V. \& Lepushyn, V.I. (2012). Leiomioma matky: etiopatohenez, profilaktyka, diahnostyka ta likuvannia [Leiomyoma of the uterus: etiopathogenesis, prophylaxis, diagnosis and treatment]. Zdorovye zhenshchiny - Health of Women, 3 (69), 52-61 [in Ukrainian].

6. Zhylka, N.Ya. (2016). Innovatsiini pidkhody do likuvannia leiomiomy matky [Innovative approaches to treatment of uterine leiomyomas]. Zdorovye zhenshchiny - Health of Women, 7 (113), 104-106 [in Ukrainian].

7. Zaporozhan, V.M., Tatarchuk, T.F. \& Hladchuk, I.Z. (Ed.) Zaporozhan, V.M. (2014). Akusherstvo ta hinekolohiia: Natsionalnyi pidruchnyk: Operatyvna hinekolohiia [Obstetrics and gynecology: National textbook: Operative gynecology]. Kyiv: VSV "Medytsyna" [in Ukrainian].

8. Panfamirov, Yu.N., Zabolotnov, V.A. \& Karapetyan, O.V. (2013). Organosberegayushchiy podkhod v lechenii miomy matki [Organosaving approach in the treatment of uterine fibroids]. Zdorovye zhenshchiny - Health of Women, 1 (77), 162-164 [in Russian]. 
9. Kosey, N.V., Vasilchenko, L.A., Sukhorebral, É.Y. \& Shokalo, I.I. (2012). Printsypy lecheniya leyomiomy matki [Principles of treatment of uterine leiomyoma]. Reproduktivnaya endokrinologiya - Reproductive Endocrinology, 1 (3), $14-20$ [in Russian].

10. Sidorova, I.S. (Ed.) (2013). Mioma matki (sovremennye aspekty etiologii, patogeneza, klassifikatsyi i profilaktiki) [Myoma of the uterus (modern aspects of etiology, pathogenesis, classification and prevention)]. Moscow: MYA [in Russian].

11. Storozhuk, M.S., Protsenko, O.O. \& Martynyshyn, O.B. (2012). Klinichna kharakterystyka zhinok reproduktyvnoho viku, khvorykh na miomu matky [Clinical characteristics of women of reproductive age, patients with myoma of the uterus]. Zdorovye zhenshchiny - Health of Women, 7 (73), 16-157 [in Ukrainian].

12. Kornatska, A.H., Raksha, I.I., Kolesnychenko, I.S. \& Chubei, H.V. (2015). Suchasni pohliady na etiolohiiu, patohenez ta likuvannia leiomiomy matky u zhinok reproduktyvnoho viku (ohliad literatury) [Modern views on the etiology, pathogenesis and treatment of uterine leiomyomas in women of reproductive age (review of literature).]. Zdorovye zhenshchiny - Health of Women, 1 (97), 10-13 [in Ukrainian].

13. Avramenko, N.V., Barkovskyi, D.Ye., Kabachenko, O.V. \& Letsyn, D.V. (2017). Suchasni pohliady reproduktoloha na etiopatohenez i likuvannia leiomiomy matky [Modern views of the reproductionist on etiopathogenesis and treatment of uterine leiomyomas]. Zaporizkyi medychnyi zhurnal - Zaporizhzhia Medical Journal, (19), 3 (102), $381-386$ [in Ukrainian]. 14. Chayka, K.V. \& Pisareva, O.L. (2013). Kompleksnoe endokhirurgicheskoe lechenie zhenshchin reproduktivnogo vozrasta s submukoznoy miomy matki [Integrated endosurgical treatment of women of reproductive age with submucous myoma of the uterus]. Medyko-sotsialni problemy simii - Medico-Social Problems of the Family, (18), 3, 63-67 [in Russian]. 15. Sharafutdinov, B.M., Akberov, R.F. \& Sharafeev, A.Z. (2015). Optimizatsiya rentgenendovaskulyarnoy embolizatsyi matochnykh arteriy pri lechenii bolnykh $\mathrm{s}$ miomami matki i matochnymi krovotecheniyami [Optimization of X-ray endovascular embolization of uterine arteries in the treatment of patients with uterine myomas and uterine bleeding]. Prakticheskaya meditsyna - Practical Medicine, 1 (86), 94-97 [in Russian].

16. Jei-Won, Moon, Chung-Hoon, Kim, Jun-Bum, Kim, Sung-Hoon, Kim, Hee-Dong, Chae, \& Byung-Moon, Kang. (2015). Alterations in uterine hemodynamics caused by uterine fibroids and their impact on in vitro fertilization outcomes. Clin. Exp. Reprod. Med., 42 (4), 163-168.

17. Yoshida, S., Ohara, N., Xu, Q., Chen, W., Wang, J. \& Nakabayashi, K. (2010). Cell-type specific actions of progesterone receptor modulators in the regulation of uterine leiomyoma growth. Semin. Reprod. Med., 28, 260-273.

18. Clark, N.A., Mumford, S.L. \& Segars, J.H. (2014). Reproductive impact of MRI-guided focused ultrasound surgery for fibroids: a systematic review of the evidence. Curr. Opin. Obstet. Gynecol., 26 (3), 151-161.

19. Deligdish, L. \& Loewenthal, M. (2014). Endometrial changes associated with myomata of uterus. J. CH. Pathol., 23, 676-680.

20. Foissac, R., Sautot Vial, N. \& Birtwisle, L. (2015). Torsion of a huge pedunculated uterine leiomyoma. Am. J. Surg., (201), 43-45.

21. Engman, M., Varghese, S., Lagerstedt Robinson, K., Malmgren, H., Hammarsjö, A. \& Byström, B. (2013). Parameswaran Grace L Lalitkumar, and Kristina Gemzell-Danielsson GSTM1 Gene expression correlates to leiomyoma volume regression in response to mifepristone treatment. PLoS One. 8 (12).

22. Mara, M., Horak, P., Kubinova, K., Dundr, P., Belsan, T. \& Kuzel, D. (2012). Hysteroscopy after uterine fibroid embolization: evaluation of intrauterine findings in 127 patients. J. Obstet. Gynaecol. Res., (38), 823-831.

23. Zepiridis, LI., Grimbizis, GF., \& Tarlatzis, B.C. (2016). Infertility and uterine fibroids. Best Pract. Res. Clin. Obstet. Gynaecol., 34, 66-73.

24. Guven, S., Kart, C., Unsal, V.A. \& Odaci, E. (2013). Intramural leoimyoma without endometrial cavity distortion may negatively affect the ICSI - ET outcome. Reprod. Biol. Endocrinol., 11, 102. doi: 10.1186/1477-7827-11-102

25. Mauro, A., Martelli, A. \& Berardinelli, P. (2014). Effect of antiprogesterone RU486 on VEGF expression and blood vessel remodeling on ovarian follicles before ovulation. PLoS One. (9), 4, e95910.

26. Pohl, O., Zobrist, R.H., \& Gotteland, J.-P. (2015). The clinical pharmacology and pharmacokinetics of ulipristal acetate for the treatment of uterine fibroids. Reprod. Sci., 22 (4), 476-483.

27. Pohl, O., Osterloh, I. \& Gotteland, J.P. (2013). Ulipristal acetate - safety and pharmacokinetics following multiple doses of 10-50 mg per day. J. Clin. Pharm. Ther., 38 (4), 314-320.

28. Fischer, K., McDannold, N.J, Tempany, C.M, Jolesz, F.A., \& Fennessy, F.M. (2015). Potential of minimally invasive procedures in the treatment of uterine fibroids: a focus on magnetic resonance-guidetfocused ultrasound therapy. Int. J. Women's Health., 7, 901-912.

29. Sabry, M., Al-Hendy, A. (2012). Innovative oral treatments of uterine leiomyoma. Hindawi Publishing Corporation, Obstetrics and Gynecology International. Article ID 943635, doi:10.1155/2012/943635

30. Samejima, T., Koga, K., Naake, H., Wada-Hiraike, O., Fujimoto, A., Fujii, T., Osuga, Y. (2015). Identifying patients who can improve fertility with myomectomy. Eur. J. Obstet. Gynecol. Reprod. Biol., 185, 28-32.

31. Shchukina, N.A., Sheina, E.N. \& Barinova, I.V. (2014). The clinical and morphological features of uterine myoma in young women. Rossiyskiy vestnik akushera ginekologa, 5, 28-31.

32. Sunkara, S.K., Khairy, M., El-Toukhy, T., Khalaf, Y., \& Coomarasamy, A. (2010). The effects of intramural fibroids without uterine cavity involvement on the outcome of IVF treatment: a systematic review and meta-analysis. Hum. Reprod., 25 (2), 418-429.

33. Suzuki, K., Nakabayashi, K. \& Yamada, A.Y. (2012). Recombinant H2 relaxin inhibits apoptosis and induces cell proliferation in ultured leiomyoma cells without affecting those in cultured normal myometrial cells. Fertil. Steril., $97,3,734-741$.

34. Tristan, M., Orozco, L.J. \& Steed, A. (2012). Mifepristone for uterine fibroids. Cochrane Database Syst., (8). CD007687. 
ЛЕЙОМИОМА МАТКИ И БЕСПЛОДИЕ (ОБЗОР ЛИТЕРАТУРЫ)

С.В. Хмиль, И.В. Корда, Ю.Б. Дроздовская, М.С. Хмиль, Н.Я. Чудийович

ГВУЗ «Тернопольский государственный медицинский университет имени И.Я. Горбачевского МЗ Украины»,

г. Тернополь, Украина

Цель: провести анализ современной отечественной и зарубежной литературы относительно причин возникновения, этиопатогенеза лейомиомы матки, современных методов лечения и влияния данной патологии на фрертильность женщины.

Материалы и методы. В исследовании использовано библиосемантический и аналитический методы.

Результаты. Во время проведения исследования изучено и проанализировано 34 источника современной отечественной и зарубежной литературы по вопросу лейомиомы матки и ее влияния на репродуктивное здоровье женщины.

Выводы. На сегодня вопрос выбора оптимальной тактики лечения лейомиомы остается довольно спорным. Комбинированная терапия с использованием современных техник (органосохраняющих операций, эмболизация маточных артерий, ссрокусированный ультразвук под контролем МРТ) и достижений фрармакотерапии (улипристал, мифепристон, аГнРГ) остаются приоритетными направлениями в современной гинекологии. С помощью данных методов лечения удается сохранить и реализовать репродуктивный потенциал женщин репродуктивного возраста с лейомиомой матки.

КЛЮЧЕВЫЕ СЛОВА: лейомиома матки; бесплодие; вспомогательные репродуктивные технологии; репродуктивное здоровье; фертильность; консервативная миомэктомия; эмболизация маточных артерий.

\section{UTERINE LEIOMYOMA AND INFERTILITY (LITERATURE REVIEW)}

S.V. Khmil, I.V. Korda, Yu.B. Drozdovska, M.S.Khmil, N.Ya. Chudiyovych

I. Horbachevsky Ternopil State Medical University, Ternopil, Ukraine

Purpose: to conduct the analysis of modern domestic and foreign literature the causes of uterine leiomyoma etiopathogenesis, modern methods of treatment and the effect of this pathology on the fertility of a woman.

Materials and Methods. The research used bibliosemantic and analytical methods.

Results. During the study, 34 sources of modern domestic and foreign literature on the issue of uterine leiomyoma and its effects on reproductive health of a woman were studied and analyzed.

Conclusions. Nowadays, the question of choosing the best treatment for leiomyomas is very controversial. Combined therapy with using of modern techniques (organ-preserving operations, uterine artery embolization, MRI focused ultrasound surgery) and the achievements of pharmacotherapy (napristal, mifepristone, agNRG) is the priority directions in modern gynecology. Such methods of treatment can help to preserve and save the reproductive potential women of reproductive age with leiomyoma of the uterus.

KEY WORDS: uterine leiomyoma; infertility; assisted reproductive technologies; reproductive health; fertility; conservative myometectomy; embolization of uterine arteries.

Рукопис надійшов до редакції 10.11.2017 р.

\section{Відомості про авторів:}

Хміль Стефан Володимирович - професор кафедри акушерства та гінекології № 1 ДВНЗ «Тернопільський державний медичний університет імені І.Я. Горбачевського МОЗ України», заслужений діяч науки і техніки України, професор, доктор медичних наук; тел.: +38(0352) 43-12-07.

Корда Інна Володимирівна - доцент кафедри акушерства та гінекології № 2 ДВН3 «Тернопільський державний медичний університет імені І.Я. Горбачевського МОЗ України», кандидат медичних наук; тел.: +38(0352) 52-38-81. Дроздовська Юлія Богданівна - аспірант кафедри акушерства та гінекології № 1 ДВНЗ «Тернопільський державний медичний університет імені І.Я. Горбачевського МОЗ України»; тел.: +38(068) 583-67-39.

Хміль Марія Стефранівна - асистент кафедри акушерства та гінекології № 1 дВН3 «Тернопільський державний медичний університет імені І.Я. Горбачевського МОЗ України»; тел.: +38(067) 846-35-34

Чудійович Наталя Ярославівна - лікар-інтерн акушер-гінеколог ТОКПЦ «Мати і дитина»; тел.: +38(098) 711-12-78. 